\title{
Features of clinical manifestation and treatment of inpatient COVID-19 cases in children
}

\author{
Charakterystyka obrazu klinicznego i leczenie pacjent w pediatrycznych \\ hospitalizowanych z powodu COVID-19
}

\author{
Department of Paediatrics and Children Infectious Diseases, Bukovinian State Medical University, Ukraine \\ Correspondence: Tetiana Bilous, Department of Paediatrics and Children Infectious Diseases, Bukovinian State Medical University, Teatralna sq., 2, Chernivtsi, 58002, Ukraine, \\ tel.: +380502213516, e-mail: bilous.tetiana@bsmu.edu.ua
}

\section{ORCID iDs}

1. Olena Koloskova (Dhttps://orcid.org/0000-0002-4402-8756

2. Tetiana Bilous (D)https://orcid.org/0000-0002-9469-401X

3. Olena Korotun iDhttps://orcid.org/0000-0003-0297-6683

\begin{abstract}
Since the beginning of the COVID-19 pandemic, many researchers have considered paediatric patients to be less vulnerable to the virus. Our study is devoted to the analysis of the dynamics of morbidity, clinical course, and treatment of children hospitalised with coronavirus disease. Aim of the study: The aim of the study was to conduct a retrospective analysis of cases of coronavirus infection in children during the $1^{\text {st }}$ year of the COVID-19 pandemic. Materials and methods: Two hundred and sixty-three clinical cases of COVID-19 in hospitalised children of Chernivtsi region (Ukraine) for the period from March 2020 to March 2021 were analysed. The peculiarities of the clinical course, symptoms, and treatment of children in the early and later periods of the pandemic were assessed. Results: It was found that the most common complaint was general weakness due to infectious-inflammatory, intoxication, and catarrhal syndromes. At the same time, over the course of the pandemic, the complaints and signs of intoxication and asthenic syndromes, infectious-inflammatory syndromes, and nonspecific neurological symptoms increased, while the rate of respiratory tract damage remained relatively stable, and in the $1^{\text {st }}$ quarter of 2021, there was a significant increase in multisystem inflammatory syndrome and community-acquired pneumonia (odds ratio, $\mathrm{OR}=2.7$ ). Conclusions: The clinical course of COVID-19 in children showed phenotypic deviations during the 1st year of the pandemic, with a tendency for an increased incidence of severe forms of the disease, resistant to the prescribed treatment.
\end{abstract}

Keywords: coronavirus disease - COVID-19, children, clinical manifestation, treatment

Streszczenie Od początku pandemii COVID-19 wielu badaczy rozważa, czy pacjenci pediatryczni są mniej podatni na zakażenie wirusem SARS-CoV-2. W niniejszej pracy przeprowadzono analizę dynamiki zachorowalności, przebiegu klinicznego i leczenia dzieci hospitalizowanych z powodu choroby koronawirusowej. Cel pracy: Celem pracy była retrospektywna analiza przypadków zakażenia koronawirusem u dzieci w pierwszym roku pandemii COVID-19. Materiał i metody: Przeanalizowano przebieg COVID-19 u 263 dzieci, które zachorowały w okresie od marca 2020 do marca 2021 roku i były hospitalizowane w obwodzie czerniowieckim (Ukraina). Ocenie poddano specyfikę przebiegu choroby, objawów klinicznych i zastosowanego leczenia we wczesnym oraz późniejszym okresie rocznej obserwacji. Wyniki: Stwierdzono, że u pacjentów pediatrycznych najczęściej występowały objawy kataralne przebiegające z ogólnym osłabieniem, spowodowane zespołem infekcyjno-zapalnym i intoksykacją w przebiegu zakażenia wirusowego. W kolejnych miesiącach trwania pandemii obserwowane objawy były wyraźnie nasilone, a poza objawami ze strony układu oddechowego występowały niespecyficzne zaburzenia neurologiczne. Ponadto w I kwartale 2021 roku odnotowano znamienny wzrost częstości występowania wieloukładowego zespołu zapalnego oraz pozaszpitalnego zapalenia płuc (iloraz szans, odds ratio, OR = 2,7). Wnioski: Przebieg kliniczny COVID-19 u dzieci wykazywał zróżnicowanie fenotypowe w pierwszym roku trwania pandemii, z tendencją do zwiększonej częstości występowania ciężkich postaci choroby, opornych na stosowane leczenie. 


\section{INTRODUCTION}

$\mathrm{T}$ he COVID-19 pandemic caused by the SARS$\mathrm{CoV}-2$ virus has had significant devastating effects on all areas of human life ${ }^{(1,2)}$. As of mid-May 2021, there were more than 2.1 million patients in Ukraine confirmed to have COVID infection according to the Ministry of Health's official data, which is equivalent to $5.16 \%$ of the country's population. The proportion of children is $5.7 \%$ of all patients (the total proportion of children 0 to 14 years old in the population of Ukraine is around 14.8\%). Within the $1^{\text {st }}$ year of the COVID-19 pandemic in Ukraine, the presence of infection was laboratory-confirmed in a total of $1,614,707$ patients, of whom $4.9 \%$ were paediatric patients, which coincides with the percentage of children among convalescents of coronavirus disease $2019^{(3)}$. Among the human losses caused by the COVID-19 pandemic, the mortality rate among children during the pandemic year was $0.06 \%$, and the age structure of deaths indicates that deaths in the age group between 0 and 9 years old are three times less common than in patients older than 10 years $(0.03 \%$ compared to $0.1 \%$ ).

Chernivtsi region is located in western Ukraine. This is the region where the $1^{\text {st }}$ case of COVID-19 in Ukraine was recorded in March 2020. According to official statistics, the incidence of the disease in the region at the end of March 2021 (after 1 year of the pandemic) was 7,572.3 per 100 thousand population, the mortality rate -144.8 per 100 thousand population and the hospital lethality rate of $1.9 \%^{(3)}$. The Chernivtsi region remains the "anti-leader," which is probably explained by the significant migration of the population, the border location of the region, and partly also the disregard for the sanitary and hygienic quarantine requirements by the population. The consequences of very high prevalence of COVID-19 in the region is another "anti-leader" indicator - absolute mortality from COVID-19, which is currently the highest in Ukraine. However, it is due not so much to medical as social preconditions, since the hospital death rate from the disease does not exceed the national rate (1.9\%).

Clinical observations of the peculiarities of COVID-19 cases in the population of Chernivtsi region during the initial 12 months of the pandemic indicate persistent maintenance of children's incidence of coronavirus disease, which is observed throughout Ukraine. In particular, during the last six months the proportion of sick children to the total number of patients fluctuated between $3.6 \%$ and $5.8 \%$, which evaluated against the background of an overall increase in the incidence of COVID-19 - showed an increase in morbidity in children and may be explained to some extent by the transient mutations of the SARS-CoV-2 virus ${ }^{(4,5)}$. There is also a certain phenotypic difference between coronavirus disease at the beginning of the COVID-19 pandemic in Ukraine and today. The variable nature of this life-threatening disease, the progressive spread of infection in the paediatric population, and the recent appearance of more severe cases of COVID-19, require careful analysis of clinical and epidemiological characteristics of this pathology, taking into account the period when it occurred.

\section{AIM OF THE STUDY}

To conduct a retrospective generalised analysis of clinical features, paraclinical markers, and features of treatment tactics in paediatric cases of COVID-19 in Chernivtsi region in the period from March 2020 to March 2021.

\section{MATERIAL AND METHODS}

A cohort of 263 clinical cases of COVID-19 in hospitalised children in Chernivtsi region for the period from March 2020 to March 2021 was studied by the method of retrospective analysis. Patients were admitted in specialised departments of the Chernivtsi Regional Children's Clinical Hospital, deployed to provide care to paediatric patients with COVID-19 in the region on average after $3.9 \pm 0.21$ days (minimum 1 day and maximum 19 days) from the onset of the disease. The average age of the patients was $6.4 \pm 0.36$ years. The proportion of boys was $51.7 \%$, and rural residents $65.8 \%$.

The examinations, verification of clinical diagnosis, and assessment of the severity of coronavirus disease were carried out according to the Protocol "Provision of medical care for the treatment of coronavirus disease (COVID-19)" No. 762 of 02.02 .2020 , as amended by the Ministry of Health of Ukraine No. 852 from 10.04.2020, No. 1653 from 21.07.2020, No. 2116 from 17.09.2020, No. 2583 from 11.11.2020, No. 2693 from 20.11.2020, No. 3094 from 31.12.2020. SARS-CoV-2 was verified by the polymerase chain reaction of reverse transcription (RT-PCR) of a nasopharyngeal swab based on its positive results. A molecular genetic PCR test detecting SARS-CoV-2 antigens was performed in hospitalised patients with suspected COVID-19. The material from isolated nasopharyngeal or combined nasopharyngeal and oropharyngeal smears was used to determine SARS-CoV-2 antigens. Coronavirus verification tests were performed in certified virological laboratories of the regional laboratory centres of the Ministry of Health of Ukraine, while other laboratory and instrumental examinations were performed in hospital laboratory facilities.

The study design included a comparative analysis of the main clinical and paraclinical indicators of the course of infection caused by the SARS-CoV-2 virus in children during the period defined above, which for convenience we divided into separate quarters of the year. Thus, the analysis of clinical cases began in the $2^{\text {nd }}$ quarter of 2020 and ended at the end of the $1^{\text {st }}$ quarter of 2021. We analysed 65 cases treated in the $2^{\text {nd }}$ quarter of 2020,90 patients who were hospitalised in the $3^{\text {rd }}$ quarter of 2020,87 children - in the $4^{\text {th }}$ quarter of 2020, and 21 children - in the $1^{\text {st }}$ quarter of 2021. Tab. 1 shows the general clinical characteristics of hospitalised children in different periods of the COVID-19 pandemic. 


\begin{tabular}{|c|c|c|c|c|c|c|}
\hline No. & Parameters & $\begin{array}{c}2^{\text {nd }} \text { quarter of 2020, } \\
n=65\end{array}$ & $\begin{array}{c}3^{\text {rd }} \text { quarter of 2020, } \\
n=90\end{array}$ & $\begin{array}{c}4^{\text {th }} \text { quarter of 2020, } \\
n=87\end{array}$ & $\begin{array}{c}1^{\text {st }} \text { quarter of 2021, } \\
n=21\end{array}$ & $p^{*}$ \\
\hline 1. & Average age of patients [years] & $6.0 \pm 0.73$ & $5.6 \pm 0.57$ & $7.3 \pm 0.62$ & $10.4 \pm 0.82$ & $\begin{array}{l}<0.05 \\
\mathrm{I}, \mathrm{II}, \mathrm{III}: \mathrm{IV}\end{array}$ \\
\hline 2. & Male gender [\%] & 40.0 & 52.2 & 57.5 & 61.9 & $\begin{array}{l}<0.05 \\
\text { I: III }\end{array}$ \\
\hline 3. & Rural residents [\%] & 84.6 & 56.7 & 69.0 & 33.3 & $\begin{array}{l}<0.05 \\
\mathrm{I}: \mathrm{II}, \mathrm{III}, \mathrm{IV}\end{array}$ \\
\hline 4. & Day of hospitalisation from disease onset [days] & $3.5 \pm 0.42$ & $3.7 \pm 0.29$ & $4.1 \pm 0.37$ & $5.5 \pm 1.02$ & $>0.05$ \\
\hline 5. & Duration of hospitalisation [days] & $10.5 \pm 0.58$ & $8.6 \pm 0.48$ & $8.4 \pm 0.32$ & $12.7 \pm 0.74$ & $\begin{array}{l}<0.05 \\
\text { I, IV: II, IIII }\end{array}$ \\
\hline
\end{tabular}

Tab. 1. General and clinical parameters of hospitalised children in Chernivtsi region in different periods of COVID-19 pandemic

According to the presented data during the one-year period of the pandemic in the population of children of Chernivtsi region who were admitted to the specialised hospital, there was a clear trend towards older age, which indirectly reflected a slightly more severe course of coronavirus disease in older children and rural population, and the predominance of boys. The gender features of coronavirus infection in children coincide with the data obtained by other researchers $^{(6)}$, who also highlight the tendency for a more severe course of the disease in males. The predominance of urban residents among hospitalised patients was interpreted by us as a consequence of non-compliance with quarantine requirements and overcrowding.

There is a clear trend towards later admission of children to the hospital in later periods of the pandemic, which was reflected in a clear increase in the duration of the hospital stage of patient treatment. At the same time, the identified features in no way affected the results of the analysis of the course of coronavirus disease during the 4 quarters of the pandemic period, but rather reflected the epidemiological features in the population of Chernivtsi children.

The study was conducted in conformity with the main principles of the Helsinki Declaration on Biomedical Research, the provisions of $\mathrm{GCH} \mathrm{ICH}$, and the order of the Ministry of Health of Ukraine dated 23.09.2009 No. 690, as amended by the Order of the Ministry of Health of Ukraine dated 12.07.2012 No. 523, in compliance with ethical principles and recommendations involving people as actors set out in the Belmont Report. The design of the study included adherence to the principles of confidentiality and respect for the child as a person incapable of self-defence, the concept of informed consent, taking into account the rule of benefit over the risk of harm, and other ethical principles for research subjects. The protocol of examination of children, the scope of examination, map of informed consent was approved by the bioethics committee at the Chernivtsi Regional Children's Clinical Hospital and the Ethics Committee of the Bukovinian State Medical University (BSMU) (Minutes No. 5 from 18.02.2021).

The results were analysed using descriptive statistical methods. For absolute values, the arithmetic mean of the sample $(M)$, and the value of standard error $(m)$ were determined.
When assessing the probability of the difference, the Student's criterion $(t)$ was determined. The difference at $p<0.05$ was considered reliable. The population analysis assessed attributive (AR) and relative risk (RR), as well as the odds ratio (OR) with the calculation of confidence intervals for relative risk, and odds ratio (95\% confidence interval, CI).

\section{RESULTS}

Fig. 1 shows the analysis of causal epidemiological contacts of hospitalised children as a possible source of infection. From the presented data it follows that the importance of intra-family contacts gradually decreases, with the growing role of extra family infections and unidentified sources of infection, which, in general, reflects the gradual decrease and neglect of quarantine requirements of the population in Chernivtsi region. In particular, as children grew older, the epidemiological role of their out-of-family contacts decreased, which was confirmed by the presence of a reliable correlation $(r=-0.14, p=0.03)$.

Considering that a similar correlation was determined between non-family sources of infection and the severity of COVID-19 ( $r=-0.2, p=0.03)$, one can conclude that the violation of quarantine requirements not only increases the persistence of SARS-CoV-2 circulation in the population of school-age and adolescent children but also exacerbates the severity of COVID-19.

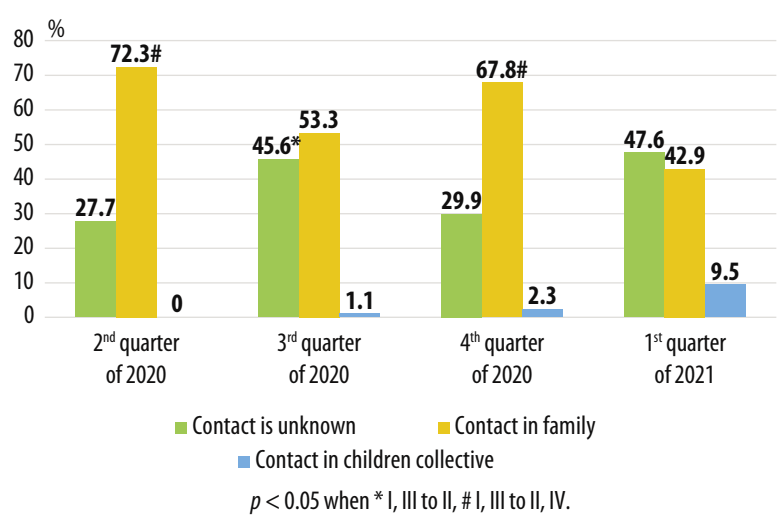

Fig. 1. Distribution of patients by epidemiological contacts as sources of SARS-CoV-2 infection 


\begin{tabular}{|c|c|c|c|c|c|}
\hline Complaints/Symptoms & $\begin{array}{c}2^{\text {nd }} \text { quarter of 2020, } \\
n=65\end{array}$ & $\begin{array}{c}3^{\text {rd }} \text { quarter of 2020, } \\
n=90\end{array}$ & $\begin{array}{c}4^{\text {th }} \text { quarter of 2020, } \\
n=87\end{array}$ & $\begin{array}{c}1^{\text {st }} \text { quarter of 2021, } \\
n=21\end{array}$ & $p$ \\
\hline General weakness/dizziness & 75.4 & 67.4 & 73.6 & 90.5 & $\begin{array}{l}<0.05 \\
\text { III III: IV } \\
\end{array}$ \\
\hline Headache & 10.8 & 11.1 & 19.5 & 28.6 & $>0.05$ \\
\hline Myalgia & 16.9 & 7.8 & 13.8 & 33.3 & $\begin{array}{l}<0,05 \\
\text { II:IV }\end{array}$ \\
\hline Cough & 35.4 & 41.1 & 53.5 & 42.9 & $\begin{array}{l}<0.05 \\
\text { I: III }\end{array}$ \\
\hline Sore throat & 21.9 & 6.7 & 6.9 & 19.0 & $\begin{array}{l}<0.05 \\
\text { I:II, III }\end{array}$ \\
\hline Rhinorrhea & 10.8 & 17.8 & 16.1 & 9.5 & $>0.05$ \\
\hline Nasal congestion & 43.1 & 32.2 & 39.1 & 38.1 & $>0.05$ \\
\hline Anosmia & 1.5 & 2.2 & 4.6 & 4.8 & $>0.05$ \\
\hline Loss of taste & 0 & 1.1 & 2.3 & 4.8 & $>0.05$ \\
\hline
\end{tabular}

Tab. 2. Presence of main clinical symptoms in children hospitalised with COVID-19 in Chernivtsi region, \%

It seemed expedient to follow the dynamic deviations of the frequency of symptom complexes in hospitalised children of Chernivtsi region in terms of the annual persistence of the COVID-19 pandemic. Tab. 2 shows the frequency of complaints in children hospitalised for COVID-19 in Chernivtsi region.

From the data presented in Tab. 2, it is possible draw conclusions on certain differences in the nature of the course of coronavirus disease which developed during the four quarters. Thus, in contrast to the beginning of the pandemic, complaints, and signs of intoxication and asthenic syndromes became more prevalent as well as infectious-inflammatory syndromes, non-specific neurological symptoms, with a relatively stable rate of damage to the respiratory tract.

At the same time, the cohorts of patients during all periods of the pandemic were dominated by patients with a moderate course of the disease, though the frequency of severe cases compared to the beginning of the pandemic in the $1^{\text {st }}$ quarter of 2021 increased almost fourfold (Fig. 2). At the same time, there was a significant decrease in the number of patients with mild coronavirus disease compared to the initial observation period, which, in our opinion, reflected better sorting of patients and management of mild cases in outpatient settings. Clinical and

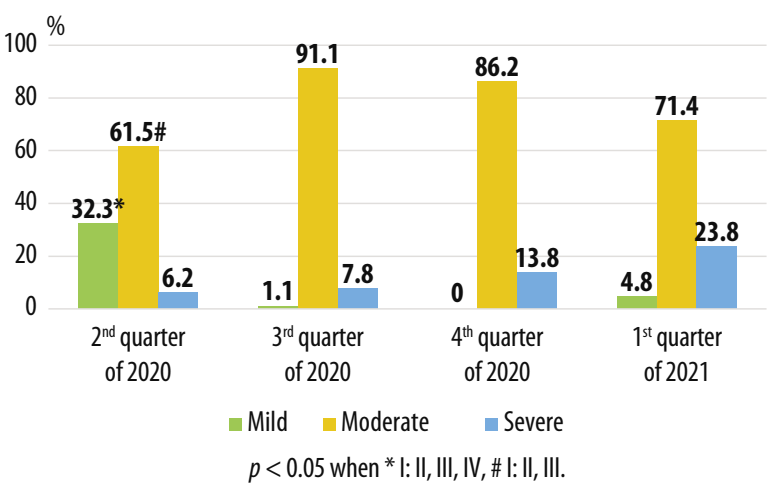

Fig. 2. Distribution of hospitalised paediatric patients with COVID-19 according to course severity epidemiological analysis of the frequency of severe cases of COVID-19 in hospitalised children showed a probable increase in their share in the $1^{\text {st }}$ quarter of 2021 compared to the previous periods of COVID-19 pandemic: relative to the $2^{\text {nd }}$ quarter of 2020 , odds ratio $(4.7 \% \mathrm{CI}$ : 1.86-12.02), RR - 1.8, absolute risk (AR) - 34.5\%, relative to the $3^{\text {rd }}$ quarter of $2020-\mathrm{OR}=3.7$ (95\% CI: $\left.1.56-8.76\right)$, $\mathrm{RR}=1.7, \mathrm{AR}=30.1$, relative to the $4^{\text {th }}$ quarter of $2020-$ $\mathrm{OR}=2.0$ (95\% CI: 0.94-4.05), $\mathrm{RR}=1.35, \mathrm{AR}=16.4$.

An explanation for such phenotypic differences in the course of coronavirus disease could be the fact that during the observation period there were significant changes in the composition of nosological forms in the hospitalised cases of infection caused by SARS-CoV-2 in Chernivtsi region children. A comparative analysis of individual nosological forms of COVID-19 in children at different observation periods is shown in Fig. 3.

Thus, the results show a dynamic decrease in the incidence of COVID-19 in the form of acute respiratory disease (ARV, flu) and bronchitis, with a significant increase in the incidence of patients with alveolar tissue lesions at the end of last year and early this year, and with increasing cases

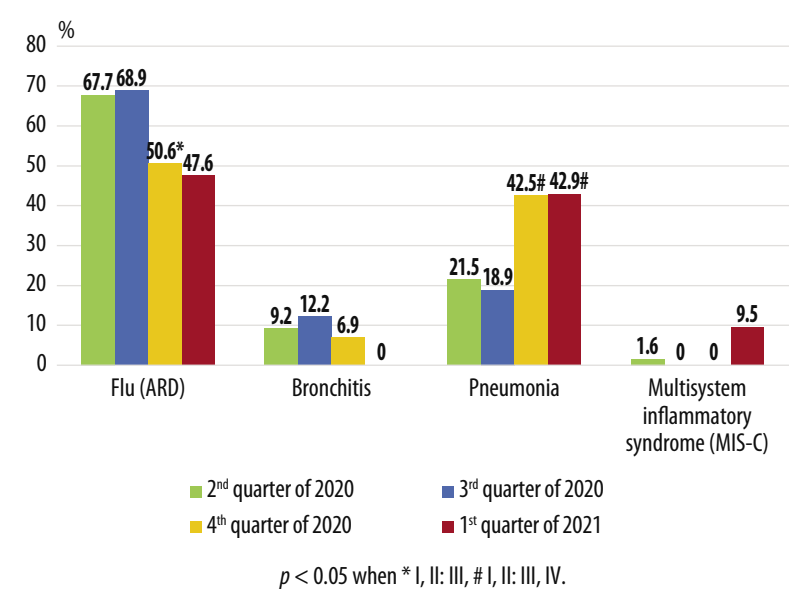

Fig. 3. Proportions of different nosological forms of COVID-19 in children of Chernivtsi region at different observation periods 


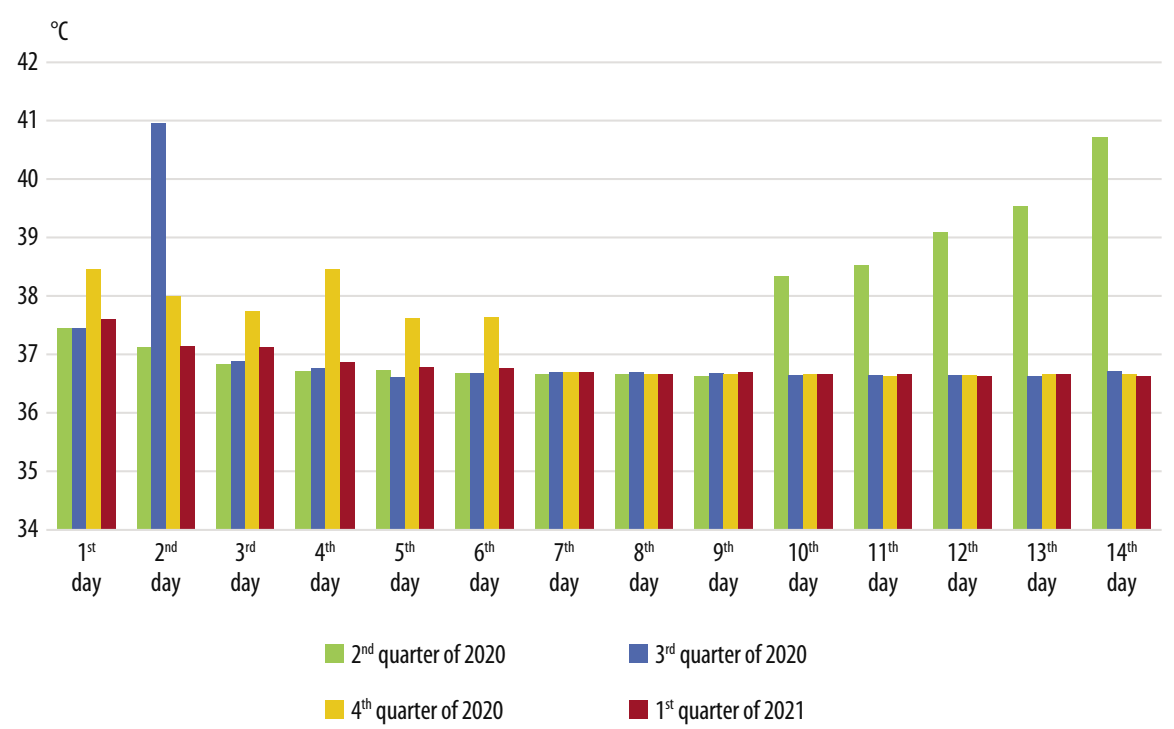

Fig. 4. Characteristics of temperature reaction in hospitalised children with coronaviral infection

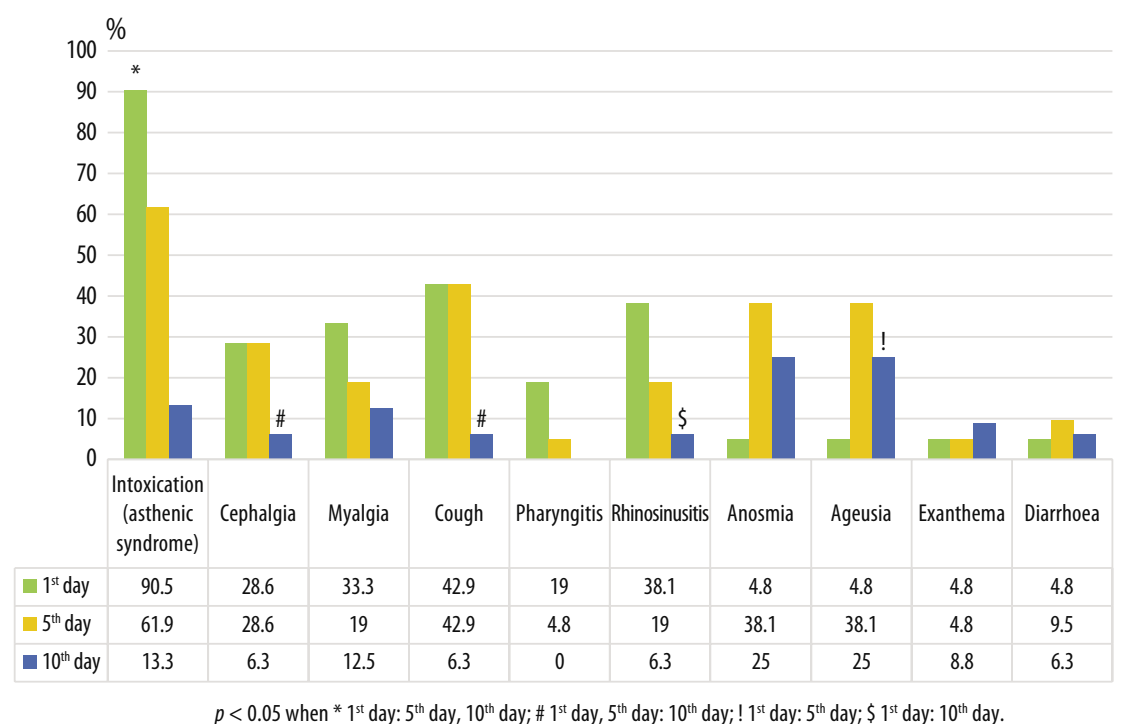

Fig. 5. Frequency of symptoms and syndromes on the $1^{\text {st }}, 5^{\text {th }}$, and $10^{\text {th }}$ days of inpatient treatment in children with COVID-19 hospitalised in Chernivtsi region in the $1^{\text {st }}$ quarter of 2021

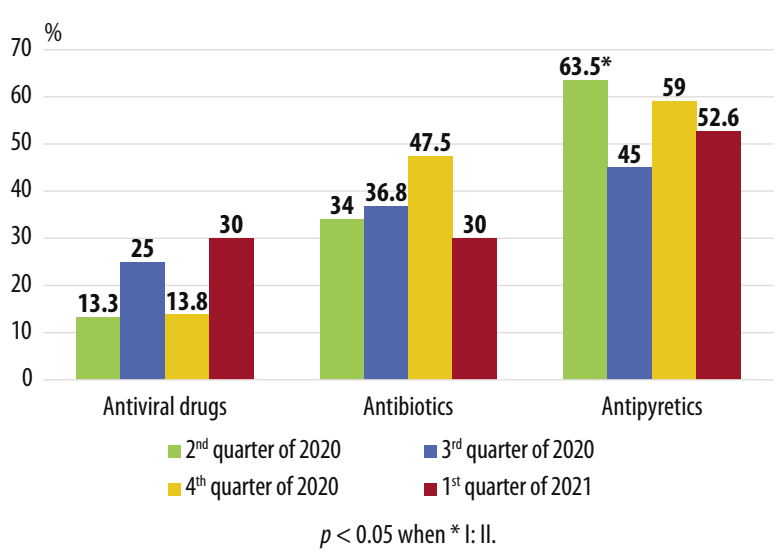

Fig. 6. Proportions of different pharmacological therapies prescribed to children with COVID-19 in Chernivtsi region

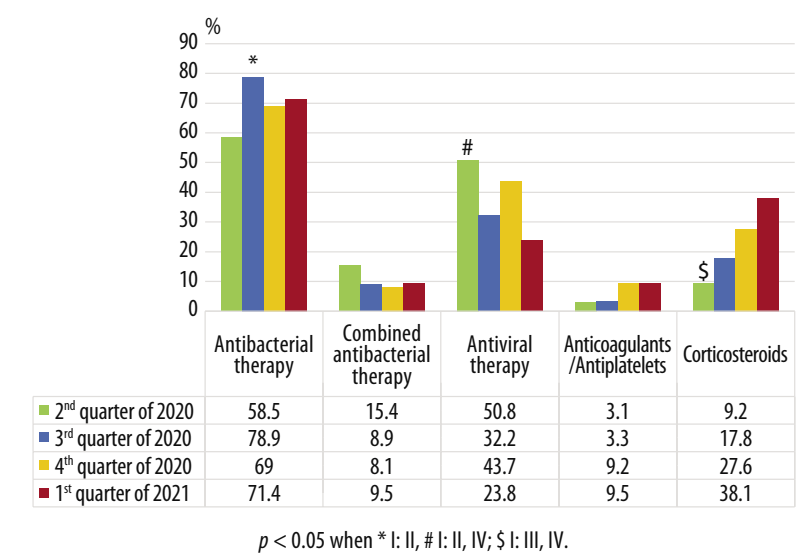

Fig. 7. Proportions of different pharmacological therapies prescribed to hospitalised children with COVID-19 in Chernivtsi region 
of multisystem inflammatory syndrome (MIS-C) in the $1^{\text {st }}$ quarter of 2021.

A aomparative analysis of temperature response of patients hospitalised in different periods of the pandemic is an interesting and relevant parameter of the COVID-16 pandemic dynamic. Fig. 4 shows the characteristics of fever in the examined patients, which emphasises differences in the nature of the inflammatory response of patients to the persistence of SARS-CoV-2.

From the point of view of comparative characteristics, it is important to analyse the dynamic of features of the clinical manifestation, signs, and symptoms of COVID-19. Fig. 5 shows the frequency of registration of individual symptoms and symptom complexes on the $1^{\text {st }}, 5^{\text {th }}$, and $10^{\text {th }}$ days of inpatient treatment.

Based on the presented data, it is clear that some of the symptoms and symptom complexes were relatively insensitive to treatment, which indicated the need for its optimisation. Thus, on the $10^{\text {th }}$ day of inpatient treatment there was a statistically significant decrease in the incidence of cough, cephalgia, and intoxication syndrome, as well as signs of rhinosinusitis compared to the $1^{\text {st }}$ day of treatment, although such symptoms as anosmia, ageusia, and gastrointestinal disorders appeared not only insensitive to the prescribed treatment but in some cases tended to increase on the $5^{\text {th }}$ day of therapy. In general, signs of neurological pathology on the $10^{\text {th }}$ day of inpatient treatment occurred in every $4^{\text {th }}$ patient, which was fundamentally greater than catarrhal symptoms, intoxication, and other clinical markers.

From this point of view, it seemed appropriate to conduct a dynamic analysis of the nature of the prescribed therapy in terms of the 12-month persistence of the COVID-19 pandemic. The analysis of the treatment prescribed to children with coronavirus disease included the study of the composition of therapy at the outpatient and inpatient stages of medical care provided to children. Fig. 6 shows a comparative analysis of the frequency of treatment with the most common drugs used in the therapy of outpatient children before they were admitted to inpatient treatment.

As shown in this figure, during the 12 months of the COVID-19 pandemic among children of Chernivtsi region, primary care physicians prescribed antiviral drugs almost three times more often, with the odds ratio of this event in the $1^{\text {st }}$ quarter of 2021 with the following level of clinical and epidemiological risk: $\mathrm{OR}=2.8$ (95\% CI: 1.36-5.73), $\mathrm{RR}=1.6, \mathrm{AR}=24.6 \%$.

Antibacterial drugs were prescribed to approximately one third of patients and increased only in the winter, reflecting another wave of increased morbidity and social tension due to the pandemic. The peculiarities of prescribing antipyretic drugs were clearly associated with the data shown in Fig. 3 and reflected certain phenotypic variants of the disease in different periods of observation. In general, slightly more than half of the patients in an outpatient stage received antipyretics.
The treatment of children with COVID-19 in the hospital in addition to antiviral and antibacterial drugs involved systemic corticosteroids and drugs of the antiplatelet/anticoagulant group. The dynamic analysis of the features of therapeutic tactics in a specialised hospital during the 12-month period of the COVID-19 pandemic is shown in Fig. 7.

Thus, the results presented in the figure indirectly reflected the more severe course of COVID-19 in hospitalised children, which coincides with the data in Fig. 1, as there is a clear trend towards more frequent use of antibacterial drugs and systemic corticosteroids. Antiplatelets/anticoagulants were prescribed three times more often than at the beginning of the pandemic, but antiviral drugs were used twice less frequently. At the same time, in the $1^{\text {st }}$ quarter of 2021, there was an increase in the risk of prescribing antibacterial therapy $(\mathrm{OR}=1.8, \mathrm{RR}=1.3, \mathrm{AR}=14.2 \%)$, antiplatelets/anticoagulants $(\mathrm{OR}=3.3, \mathrm{RR}=1.6, \mathrm{AR}=27.1 \%)$, and systemic corticosteroids $(\mathrm{OR}=6.1, \mathrm{RR}=2.0, \mathrm{AR}=40.0 \%)$.

\section{DISCUSSION}

The study presents a dynamic analysis of the clinical features characterising the course of COVID-19 in the paediatric population in Chernivtsi region who were hospitalised between March 2020 and March 2021 in inpatient departments with signs of infection caused by the SARS-CoV-2 virus. One can state that the most frequent complaint observed in residents of Chernivtsi region was malaise attributed to infectious-inflammatory, intoxication, and catarrhal syndromes, and therefore coincided with the results reported by other researchers in the literature on the main complaints of children with COVID-19 $9^{(7,8)}$. In contrast to the onset of the pandemic, at the beginning of 2021 complaints and signs of intoxication and asthenic syndromes, infectious-inflammatory syndromes, non-specific neurological symptoms significantly increased, with a relatively stable rate of damage to the respiratory tract.

Fever could be considered as a protective and adaptive response of the body to the infectious process. At the start of the pandemic, there was a normalization of pathological body temperature in children, beginning with the $3^{\text {rd }}$ day, with its subsequent increase, starting from the $10^{\text {th }}$ day of inpatient treatment, which coincided with the development of complications (lower airway damage). Then, approximately from the middle of the $1^{\text {st }}$ year of the pandemic, the children's body temperature response changed significantly and could be suspected anergy. Moreover, according to the observations reported by paediatricians who provide care to children with COVID-19, at the end of the $1^{\text {st }}$ quarter of 2021, new signs of this pathology appeared, consisting in rapid damage to the lower respiratory tract, with normal or slightly elevated body temperature, against the background of increasing the indicators of cytokine storm and thrombosis and severe course of the disease requiring oxygen support. This coincides with the clinical signs of intoxication and asthenia, and points towards 
certain phenotypic differences in the current course of the disease caused by SARS-CoV-2 ${ }^{(9-11)}$.

In the later periods of observation, there was a significant decrease in the number of patients with mild coronavirus disease compared to the initial observation period, which, in our opinion, reflected a better sorting of patients and improved management of mild cases in outpatient facilities. At the same time, an increase in the number of cases of multisystem inflammatory syndrome in the $1^{\text {st }}$ quarter of 2021 was revealed. Thus, the indicators of clinical and epidemiological risk of multisystem inflammatory syndrome in the $1^{\text {st }}$ quarter of 2021 were 6.5 times higher than at the onset of the pandemic $(\mathrm{OR}=6.5, \mathrm{RR}=1.8, \mathrm{AR}=37.7 \%)$, and for community-acquired pneumonia, these risk indicators reached: $\mathrm{OR}=2.7, \mathrm{RR}=1.6, \mathrm{AR}=24.5 \%$. It is possible that these data only partially reflect the triage of patients when deciding on the place of their treatment, but at the same time clearly demonstrate the growth of severe and systemic forms of coronavirus disease in children ${ }^{(8,12)}$. The role of late admission of patients to the hospital, expansion of children's contacts, and violation of quarantine requirements should be considered as well, while another explanation for such phenotypic changes may be the described mutations of the SARS-CoV-2 virus $^{(13,14)}$. In the treatment of hospitalised paediatric patients, there is a clear trend towards more frequent use of antibacterial drugs and systemic corticosteroids, with an increased risk of antibacterial therapy ( $\mathrm{OR}=1.8$ ), antiplatelet agents/anticoagulants $(\mathrm{OR}=3.3)$, and systemic corticosteroids $(\mathrm{OR}=6.1)$.

\section{CONCLUSIONS}

During over a year of the COVID-19 pandemic, Chernivtsi region was one of the "anti-leaders" in coronavirus morbidity and mortality, with the proportion of children with COVID-19 exhibiting a growing tendency. Dynamic analysis of the features of the course of COVID-19 in children showed phenotypic deviations of the disease with insensitivity to the prescribed treatment of nonspecific symptoms of the nervous system and gastrointestinal tract, decreasing duration and severity of fever, and increasing incidence of pneumonia $(\mathrm{OR}=2.7)$ and multisystem inflammatory syndrome $(\mathrm{OR}=6.5)$. During the one-year period of the pandemic, there were changes in therapeutic tactics. Specifically, the hospital rate of prescribing systemic corticosteroids increased 6.1 times, and antiplatelets/anticoagulants three times.

\section{Conflict of interest}

The authors do not report any financial or personal connections with other persons or organisations which might negatively affect the contents of this publication and/or claim authorship rights to this publication.

\section{References}

1. Ludvigsson JF: Systematic review of COVID-19 in children shows milder cases and a better prognosis than adults. Acta Paediatr 2020; 109: 1088-1095.

2. Rabinowicz S, Leshem E, Pessach IM: COVID-19 in the pediatric population - review and current evidence. Curr Infect Dis Rep 2020; 22: 29.

3. [Operational information on the spread of coronavirus infection 2019-nCoV of the Ministry of Health of Ukraine]. Available from: https://moz.gov.ua/article/news/operativna-informacijapro-poshirennja-koronavirusnoi-infekcii-2019-cov19.

4. Korber B, Fischer WM, Gnanakaran S et al.; Sheffield COVID19 Genomics Group: Tracking changes in SARS-CoV-2 spike: evidence that D614G increases infectivity of the COVID-19 virus. Cell 2020; 182: 812-827.e19.

5. Awadasseid A, Wu Y, Tanaka Y et al.: SARS-CoV-2 variants evolved during the early stage of the pandemic and effects of mutations on adaptation in Wuhan populations. Int J Biol Sci 2021; 17: 97-106.

6. Bhuiyan MU, Stiboy E, Hassan MZ et al.: Epidemiology of COVID-19 infection in young children under five years: a systematic review and meta-analysis. Vaccine 2021; 39: 667-677.

7. Cui X, Zhao Z, Zhang T et al.: A systematic review and metaanalysis of children with coronavirus disease 2019 (COVID-19). J Med Virol 2021; 93: 1057-1069.

8. Rostad BS, Shah JH, Rostad CA et al.: Chest radiograph features of multisystem inflammatory syndrome in children (MIS-C) compared to pediatric COVID-19. Pediatr Radiol 2021; 51: 231-238.

9. Ma X, Liu S, Chen L et al.: The clinical characteristics of pediatric inpatients with SARS-CoV-2 infection: a meta-analysis and systematic review. J Med Virol 2021; 93: 234-240.

10. Badal S, Thapa Bajgain K, Badal S et al.: Prevalence, clinical characteristics, and outcomes of pediatric COVID-19: a systematic review and meta-analysis. J Clin Virol 2021; 135: 104715.

11. Nallasamy K, Angurana SK, Jayashree M et al.; Pediatric COVID Management Team: Clinical profile, hospital course and outcome of children with COVID-19. Indian J Pediatr 2021; 88: 979-984.

12. Syangtan G, Bista S, Dawadi P et al.: Asymptomatic SARS-CoV-2 carriers: a systematic review and meta-analysis. Front Public Health 2021; 8: 587374.

13. Chen J: Pathogenicity and transmissibility of 2019-nCoV-A quick overview and comparison with other emerging viruses. Microbes Infect 2020; 22: 69-71.

14. Meo SA, Alhowikan AM, Al-Khlaiwi T et al.: Novel coronavirus 2019-nCoV: prevalence, biological and clinical characteristics comparison with SARS-CoV and MERS-CoV. Eur Rev Med Pharmacol Sci 2020; 24: 2012-2019. 